\title{
BIOREGULATOR APPLICATION, AGRONOMIC EFFICIENCY, AND QUALITY OF SOYBEAN SEEDS
}

\author{
Marizangela Rizzatti Ávila ${ }^{1}$; Alessandro de Lucca e Braccini ${ }^{1 *}$; Carlos Alberto Scapim ${ }^{1}$; \\ Leandro Paiola Albrecht ${ }^{2}$; Telmo Antônio Tonin ${ }^{1}$; Marcibela Stülp ${ }^{2}$ \\ ${ }^{1}$ UEM - Depto. de Agronomia, Av. Colombo, 5790 - 87020-900 - Maringá, PR - Brasil. \\ ${ }^{2}$ UEM - Programa de Pós Graduação em Agronomia. \\ *Corresponding author <albraccini@uol.com.br>
}

\begin{abstract}
The application of vegetal bioregulators has shown promising results, mainly in cultures that have already reached a high level of technology. Based on this context an experiment was carried out with the objective of evaluating agronomic traits of plants, such as yield and quality of seeds, produced by applying bioregulators to a soybean crop. For this purpose, the following treatments were carried out: before sowing - seed treatment $\left(25,50\right.$ and $75 \mathrm{~mL}$ for $100 \mathrm{~kg}^{-1}$ seeds); during sowing time - spraying on the sowing lines (pulverization onto the sowing lines) $\left(50,100\right.$ and $150 \mathrm{~mL} \mathrm{ha}^{-1}$ ); between stages $\mathrm{V}_{5}$ and $\mathrm{V}_{6}\left(25,50\right.$ and $\left.75 \mathrm{~mL} \mathrm{ha}^{-1}\right)$; and the control - no treatment. Emergence speed, final seedling emergence, number of pods and seeds per plant, average height of plants, first pod insertion height, duration of the cycle, final stand, degree of plant layering, and the yield and weight of one thousand seeds were evaluated. The quality of seeds was evaluated based on germination, classification of seedling vigor, tetrazolium, health test and the quantity of oil and protein tests. The highest yield of grains, an increase of $92 \%$ as compared to the control, was obtained when using the product at a dose of $75 \mathrm{~mL} \mathrm{ha}^{-1}$. The best quality seeds and the highest oil and protein content were obtained from seeds produced by plants whose seeds were treated before sowing time using the bioregulator ( $75 \mathrm{~mL}$ for $100 \mathrm{~kg}^{-1}$ seeds).
\end{abstract}

Key words: growth regulator, yield, vigor, germination

\section{APLICAÇÃO DE BIORREGULADOR, DESEMPENHO AGRONÔMICO E QUALIDADE DE SEMENTES DE SOJA}

\begin{abstract}
RESUMO: A aplicação de bioreguladores vegetais tem apresentado resultados promissores, principalmente nas culturas que atingiram nível elevado de tecnologia. Com base nesse contexto, instalou-se um experimento, com objetivo de avaliar o desempenho agronômico das plantas, a produtividade e a qualidade das sementes produzidas com aplicação de biorregulador na cultura da soja. Para tal, realizaram-se os seguintes tratamentos: antes da semeadura, tratamento de sementes (25; 50 e $75 \mathrm{~mL}$ para $100 \mathrm{~kg}^{-1}$ de sementes); na semeadura, pulverização dirigida no sulco de plantio (50; 100 e $\left.150 \mathrm{~mL} \mathrm{ha}^{-1}\right)$; entre os estádios $\mathrm{V}_{5} \mathrm{e} \mathrm{V}_{6}$, pulverização foliar $\left(25 ; 50 \mathrm{e} 75 \mathrm{~mL} \mathrm{ha}^{-1}\right)$ mais a testemunha sem tratamento. Avaliou-se a velocidade de emergência, emergência final das plântulas, número de vagens e de sementes por planta, altura média das plantas, altura de inserção das primeiras vagens, duração do ciclo, estande final, grau de acamamento das plantas, produtividade e massa de mil sementes; a qualidade das sementes por meio dos testes de germinação, classificação do vigor das plântulas, tetrazólio e sanidade. Foram avaliados, ainda, os teores de óleo e de proteínas nas sementes. A maior produtividade de sementes foi obtida com a aplicação foliar do produto na dose de $75 \mathrm{~mL} \mathrm{ha}{ }^{-1}$ com incremento superior a $92 \%$ em relação à testemunha. A melhor qualidade de sementes e os maiores teores de óleo e proteínas foram obtidos nas sementes oriundas de plantas que tiveram suas sementes tratadas antes da semeadura com $75 \mathrm{~mL} 100 \mathrm{~kg}^{-1}$ do bioregulador.

Palavras-chave: regulador de crescimento, rendimento, vigor, germinação
\end{abstract}

\section{INTRODUCTION}

Soybean is the main crop currently grown in Brazil; therefore, it is important to promote intense research activity in order to obtain information that may increase their yield. Since increasing productivity is becoming more necessary and difficult, bioregulators may be an extremely useful tool (Nickell, 1988). Bioregulators are organic compounds that, in low concentrations, inhibit, promote or modify the morphological and physiological processes of plants. These natural or synthetic substances can be applied directly 
to the plants (leaves, fruit and seeds), provoking alterations of vital and structural processes in order to increase yield. Through these substances, it is possible to interfere with several physiological and/or morphological processes, including germination and vegetative growth, among other features. This interference can occur through applying these substances via seed, soil or leaf; it is necessary for them to be absorbed so that they can exercise their activity (Castro \& Melotto, 1989).

Agricultural application of vegetal bioregulators is becoming a useful practice that has improved the yield of beans, corn and soybeans (Alleoni et al., 2000; Vieira \& Castro, 2001; Vieira \& Castro, 2004; Braccini et al., 2005). These substances, when applied in low concentrations to seeds or the aerial parts of plants, enhance the performance of vital physiological processes, exerting a positive influence on crop yield (Casillas et al., 1986).

The effects of treating plants with bioregulators on the germination and vigor of seeds, as well as the best form and dose to apply, are still insufficiently explored in the literature. Therefore, the objective of this work was to evaluate not only the agronomical performance of the plants, but also the yield and quality of seeds produced by using bioregulators on a soybean crop.

\section{MATERIAL AND METHODS}

This experiment was undertaken in Maringá, the northwestern region of the state of Paraná, Brazil ( $23^{\circ} 25^{\prime} \mathrm{S}$ and $51^{\circ} 57^{\prime} \mathrm{W}$, average altitude $540 \mathrm{~m}$ ). The soil of the experimental area was classified as Rodhic Haplorthox. The region's predominant climate type is Cfa (wet mesothermic; abundant showers in summer; dry winter and hot summer), according to Köppen (IAPAR, 1987). Figure 1 shows the daily registered data for local rainfall, maximum and minimum daily temperatures during the period of the field experiment.

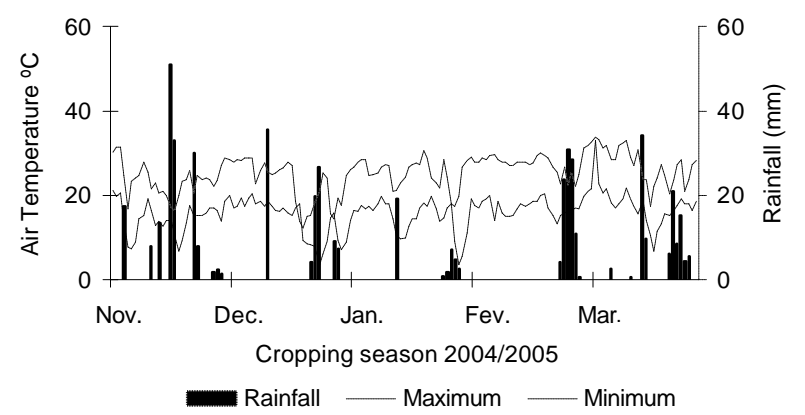

Figure 1 - Rainfall and maximum and minimum daily temperatures during the experiment conduction. [Source: Iguatemi Experimental Farm of the State University of Maringá (UEM)].
Fertilization comprised $60 \mathrm{~kg} \mathrm{ha}^{-1}$ of $\mathrm{P}_{2} \mathrm{O}_{5}$, simple superphosphate form, and $40 \mathrm{~kg} \mathrm{ha}^{-1}$ of $\mathrm{K}_{2} \mathrm{O}$, as $\mathrm{KCl}$. A no-tillage system was employed, and oat straw that had been sowed during the winter and dried with glyphosate at $5 \mathrm{~L} \mathrm{ha}^{-1} 30$ days before the sowing of soybean was used.

Soybean seeds from an early soybean cultivar CD 202 were manually sowed in lines $0.50 \mathrm{~m}$ apart and approximately $5 \mathrm{~cm}$ deep with a density of 20 seeds per meter. Lots comprised six lines seven meter long. For accuracy of evaluation, only the four central lines were taken into account. Since $0.5 \mathrm{~m}$ were eliminated from each extremity, the useful area totaled $12 \mathrm{~m}^{2}$. Sowing was carried out on November $13^{\text {th }}$, 2004 and treatments consisted of three forms of application and three doses of the bioregulator ST10X and a control. Application of the product and respective doses was as follows: seed treatment $(25,50$ and $75 \mathrm{~mL} 100 \mathrm{~kg}^{-1}$ of seeds); pulverization of sowing lines (50, 100 and $\left.150 \mathrm{~mL} \mathrm{ha}^{-1}\right)$ and leaf spraying $(25,50$ and $75 \mathrm{~mL} \mathrm{ha}^{-1}$ ).

The bioregulator ST10X was composed of 0.5 $\mathrm{g} \mathrm{L}^{-1}$ Indole Butyric Acid (auxin), $0.9 \mathrm{~g} \mathrm{~L}^{-1}$ kinetin (cytokine) and $0.5 \mathrm{~g} \mathrm{~L}^{-1}$ gibberellic acid (gibberellin). Seeds were treated with the fungicide Carboxin + Thiram at a dose of $250 \mathrm{~mL} 100 \mathrm{~kg}^{-1}$ seeds and 50 $\mathrm{mL}$ water. After treatment by fungicide, seeds were weighed and separated for other treatments. Apart from the fungicide, seeds in treatment lots and the control were also treated with cobalt + molybdenum $(0.8 \%+$ $0.8 \%)$ at $150 \mathrm{~mL} 50 \mathrm{~kg}^{-1}$ seeds, coupled to peat inoculant (250 g $50 \mathrm{~kg}^{-1}$ seeds). Treatment of seeds with bioregulator before sowing was carried out as follows: fungicide + bioregulator + cobalt and molybdenum + peat inoculant.

Sowing was done immediately after treatment and seed inoculation. In the case of treatments with spraying of sowing lines, holes were dug during sowing, seeds were uniformly distributed, and bioregulator was directly applied to seeds before the holes were closed. Shoulder-strapped $\mathrm{CO}_{2}$-propelled spraying equipment was used, under a constant pressure of $40 \mathrm{kPa}$. Equipped with a XR 110:02 spray nozzle, the equipment was operated at a height of $20 \mathrm{~cm}$ from the target at 1 $\mathrm{m} \mathrm{s}^{-1}$ speed, with a $100 \mathrm{~L} \mathrm{ha}^{-1}$ flow rate.

Leaf spraying was done between soybean $\mathrm{V}_{5}$ and $\mathrm{V}_{6}$ stage development, or rather, when plants had four to five trifolium accessions (Fehr et al., 1971). Shoulder-strapped $\mathrm{CO}_{2}$-propelled spraying equipment was used for leaf application, under a constant pressure of $40 \mathrm{kPa}$. Equipped with a XR 110:02 spray nozzle, the equipment was operated at a height of 50 $\mathrm{cm}$ from the target at $1 \mathrm{~m} \mathrm{~s}^{-1}$ speed, with a $200 \mathrm{~L} \mathrm{ha}^{-1}$ flow rate. 
Culture management was as prescribed for the region's production system (Embrapa Soja, 2004). Weeds were controlled by applying post-emergence herbicide (Fluazifop-p-butyl + Fomesafen) at doses recommended by the manufacturer $\left(2.0 \mathrm{~L} \mathrm{ha}^{-1}\right)$, complemented by hoeing. Caterpillar and bug control was done, when required, by systematic spraying of insecticide Endosulfan at doses recommended by manufacturer; namely, $0.25 \mathrm{~L} \mathrm{ha}^{-1}$ in the case of caterpillars and $1.25 \mathrm{~L} \mathrm{ha}^{-1}$ in the case of stink bugs, throughout the culture cycle.

The emergence speed, final emergence of seedlings and number of days for maturation were evaluated during culture development. Number of pods and seeds per plant, average height of plants, first pod insertion height, and final stand and degree of plant layering were determined at stage $R_{8}(95 \%$ of mature pods).

Seedling emergence was evaluated for the lots' useful area, or rather, for the four central lines. Daily records of the amount of seedlings were taken until a steady level was reached. The total percentage of emerged seedlings was evaluated on the twenty-first day after seed sowing, or rather, when new seedlings stopped emerging (Popinigis, 1985).

Emergence speed was determined together with the seedling emergence test. The counting of emerged seedlings, those with the cotyledons completely above soil level, was registered daily, without any being discharged. A cumulative value was thus obtained. The number of emerged seedlings at each count was obtained by subtracting the registered value from that registered on the previous day. Emergence speed (ES) was calculated by the number of seedlings that emerged in each report, using the following formula for Emergence Speed (Edmond \& Drapala, 1958):

$\mathrm{ES}=\left(\mathrm{N}_{1} \mathrm{G}_{1}+\mathrm{N}_{2} \mathrm{G}_{2}\right)+\ldots+\left(\mathrm{N}_{\mathrm{n}} \mathrm{G}_{\mathrm{n}}\right) / \mathrm{G}_{1}+\mathrm{G}_{2}+\ldots+\mathrm{G}_{\mathrm{n}}$ $E S=$ emergence speed (days) $; G=$ number of emerged seedlings in each counting; $\mathrm{N}=$ number of sowing days at each count.

Number of days until maturation refers to the period comprising up to $50 \%$ of plant emergence of useful area at the $\mathrm{R}_{8}$ stage, or full maturation, according to the scale developed by Fehr et al. (1971). So that plant height and first pod insertion height could be determined, fifteen plants in the lots' useful area were evaluated, at random, with a millimeter ruler. Whereas plant height was measured from soil level to the last pod insertion, first pod insertion was measured from soil level to the first pod insertion.

Number of pods and seeds per plant were evaluated at the full maturation stage $\left(\mathrm{R}_{8}\right)$ by counting the pods and seeds of the 15 randomly chosen plants in the lots' useful area. The final stand was evaluated from one-meter samples of each useful area line, and results were expressed in number of plants per linear meter. Scores from 1 to 5 (including decimal point) were used to evaluate degree of plant layering, according to the following scale: $1=0 \%$, no plant layering in useful area; $2=25 \%$ plant layering in useful area; $3=50 \%$ plant layering in useful area; $4=75 \%$ plant layering in useful area; $5=100 \%$ plant layering in useful area.

Plants were harvested manually eight days after $R_{8}$ stage development. Seeds were then shelled by a stationary threshing machine; cleaned with sifters; dried naturally and finally stored in Kraft paper bags. Yield was calculated from seed yield in each lot. For yield calculation, seed moisture rate was determined by the vapor hauling method at $105 \pm 3^{\circ} \mathrm{C}$ (Brasil, 1992), adjusted to $13 \%$. The weight of one thousand seeds was determined by weighing eight subsamples made up of 100 seeds for each field repetition, using an analytical scale (Brasil, 1992) and multiplying the results by ten.

Physiological and health qualities and quantity of oil and protein in seeds were evaluated by the following tests:

Germination test: Four subsamples with 50 seeds used for each repetition were put between three paper towels and soaked in distilled water $(2.5 \times$ dry paper weight soaked in water) to germinate. They were then rolled up and taken to the germinator to maintain a constant temperature of $25 \pm 1^{\circ} \mathrm{C}$. Evaluations were taken on the fifth (first count) and eighth (final count) days, counting the percentage of normal seedlings according to Seed Analysis Rules (Brasil, 1992).

Classification of seedling vigor: Classification of seedling vigor was carried out along with the germination test. Normal seedlings were classified into strong (high vigor) and weak (low vigor) categories. In the first count, five days after sowing, all normal seedlings which were well-developed and morphologically perfect, or rather, had neither fissures nor injuries, were removed and discarded after being registered as strong/normal. The remaining seedlings were maintained until the final count. Eight days after sowing, they were evaluated as either normal or as abnormal seedlings.

Normal seedlings in the final count were classified as strong and weak. The latter revealed fissures or defects in their structure, albeit with no abnormality in the seedling. Results were expressed in percentage of strong normal seedlings (high vigor) counted in the first and final counts of the test (Nakagawa, 1999). 
Tetrazolium Test: Four subsamples with 50 seeds per experimental unit were used for the tetrazolium test. They were conditioned in paper towels, soaked with distilled water, and placed in a germinator at a temperature of $25^{\circ} \mathrm{C}$ for 16 hours. Seeds were then transferred to $50 \mathrm{~mL}$ plastic cups, totally submerged into a tetrazolium solution (2,3,5-triphenyl-2H-tetrazolium chloride) with a concentration of $0.075 \%$, and kept at a temperature of $40^{\circ} \mathrm{C}$ for approximately 180 minutes in the dark inside a germination chamber. After staining, seeds were washed with running water and kept submerged until evaluation time. They were then individually evaluated, sectioned longitudinally and symmetrically with a razor blade, and classified according to the criteria of França Neto et al. (1998). Viability was classified by the ratio of seeds belonging to classes 1 to 5; vigor level was classified by classes 1 to 3 , whereas lack of viability was classified by classes 6 to 8 . Vigor and viability potentials were expressed as percentages (França Neto et al., 1999).

Protein content: Protein content was determined by the Kjeldahl method (total nitrogen), as recommended by the Association of Official Analytical Chemists (AOAC, 1975), with modifications. Seeds from each field repetition were ground in a mill for 60 seconds at $17,000 \mathrm{rpm}$. Four subsamples containing $0.2 \mathrm{~g}$ of ground soybean flour were placed in test tubes with 2 $\mathrm{g}$ of a catalysis (copper sulfate and selenium powder) and $5 \mathrm{~mL}$ of concentrated sulfuric acid and analyzed. Tubes were gradually heated up to $350^{\circ} \mathrm{C}$ on a block digestor for $2.5 \mathrm{~h}$, up to the digestion phase for organic matter. After digestion, the released ammonia distillation phase was started by a reaction to sodium hydroxide (50\%), which was collected in $4 \%$ boric acid solution. Titration was carried out in standard chlorohydric acid solution $\left(1 \mathrm{~mol} \mathrm{~L}^{-1}\right)$, and $99.7 \%$ nitrogen was recovered. Nitrogen contents were multiplied by dry matterbased factor 6.25 to determine total protein content.

Oil content: For the determination of total lipids (oil), Soxhlet extractor and petroleum ether as solvent were used according to the procedure described by the Adolfo Lutz Institute Analytical Rules (IAL, 1985), with a 6h reflux. Four subsamples of $2 \mathrm{~g}$ soybean flour from seed samples from each repetition were used. Results were expressed as extracted oil percentage.

Health test: Health test was carried out by the filterpaper method in which 100 seeds, divided into four subsamples of 25 , were used. These were placed on four filter papers, soaked in sterilized distilled water, and autoclaved. Finally, they were conditioned in Gerboxtype plastic boxes. Incubation occurred at room temperature at approximately $25^{\circ} \mathrm{C}$ in light/dark cycles of
$12 \mathrm{~h}$ of light from fluorescent lamps and $12 \mathrm{~h}$ of darkness, over a period of seven days. Fungi on seeds were then evaluated under a magnifying glass with light and stereoscopic microscopes (Henning, 1994).

Experiment design consisted of completely randomized blocks with four replications, while treatments were arranged into a hierarchical scheme including one control (no application). Analysis of each combination (dose/form of application) was carried out by linear regression. Best application forms for each dose were compared to the control using the Dunnett test $(p<0.05)$.

\section{RESULTS AND DISCUSSION}

So that the combination of application doses and forms could be compared with the control, the highest percentage rates of seedling emergence were obtained from seed treatments with bioregulator at 25 and $50 \mathrm{~mL} 100 \mathrm{~kg}^{-1}$ seed concentrations (Table 1). Further, seeds that received treatment in the sowing line had lower emergence percentages when compared to the control, regardless of the dose.

Results on the emergence percentage of seedlings on lots treated with bioregulator by leaf spraying (Treatments 8; 9 and 10) did not differ from the control since they were treated only within the range of stages $\mathrm{V}_{5}$ and $\mathrm{V}_{6}$. There was no difference $(p>0.05)$ among treatments applied on seeds (Treatments 2;3 and 4) in the evaluation of seedling emergence speed; this fact has also been reported for Treatments 7; 8; 9 and 10, when compared to the control. Seeds that received treatment in the sowing line (Treatments 5 and 6) required 8.28 and 8.19 days, respectively, to emerge, whereas the control required 7.91 days. Therefore, Treatments 5 and 6 were better-placed in time as compared to control.

Faster seedling emergence results were reported by Howell (1963), cited by Castro (1980), when soybean seeds were treated with gibberellin. Marcos Filho (2005) considered gibberellins accountable for performance on the digestion of seed reserves, stimulated by the synthesis and activity of hydrolytic enzymes. Moreover, $\mathrm{GA}_{3}$ (gibberellin) induces mRNA, (Morais et al., 2002) which in turn produces the synthesis of $\alpha$-amilase, protease, nuclease and others. On the other hand, Larcher \& Prado (2000) commented on auxin's effects on membrane permeability and primary root growth during germination.

The duration of the culture cycle was shorter for treatments whose bioregulator application was done on seeds (Treatments 2 to 4 ) and by leaf spraying (Treatments 8 to 10), with different doses of the product. Treatments were effective since they reduced the culture cycle to approximately two days. Guided 
spraying of the bioregulator on the sowing line did not affect culture cycle.

Although auxin and cytokinin may delay senescence (Taiz \& Zeizer, 2004), the shortest cycle in Treatments 2 and 3 may be explained by higher emergence speed; in the case of foliar treatments, the application of bioregulator between stages $\mathrm{V}_{5}$ and $\mathrm{V}_{6}$ may have stimulated floral induction. The exogen gibberellin may substi- tute for the endogenous age trigger on autonomous flowering, anticipating the reproductive phase and consequently reducing the culture cycle (Taiz \& Zeizer, 2004).

Treatments with the highest number of pods and seeds per plant were those in which spraying was directed on the sowing line (Treatments 5 to 7). They had higher numbers when compared to the control (Table 2). The results of Treatments 2, 3, 4, 8, and 9

Table 1 - Means of total percentage of seedling emergence in field, speed of emergence and cycle duration in response to different doses and forms of bioregulator application on soybean cultures as compared to the control (2004/2005).

\begin{tabular}{|c|c|c|c|}
\hline Treatment ${ }^{1} /$ Dose & Seedling Emergence & Speed of Emergence & Cycle \\
\hline & $\%$ & \multicolumn{2}{|c|}{ 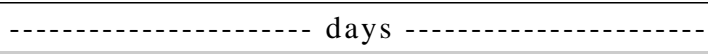 } \\
\hline 1. CONTROL & $45^{2}$ & $7.91^{2}$ & $116.25^{2}$ \\
\hline 2. ST (25 mL $\left.100 \mathrm{~kg}^{-1}\right)$ & $68^{+}$ & $7.82^{\mathrm{ns}}$ & $114.50^{-}$ \\
\hline 3. ST $\left(50 \mathrm{~mL} 100 \mathrm{~kg}^{-1}\right)$ & $66^{+}$ & $7.65^{\mathrm{ns}}$ & $114.00^{-}$ \\
\hline 4. ST $\left(75 \mathrm{~mL} 100 \mathrm{~kg}^{-1}\right)$ & $54^{\mathrm{ns}}$ & $7.87^{\text {ns }}$ & $114.50^{-}$ \\
\hline 5. SL $\left(50 \mathrm{~mL} \mathrm{ha}^{-1}\right)$ & $17^{-}$ & $8.28^{+}$ & $116.50^{\mathrm{ns}}$ \\
\hline 6. SL (100 mL ha $\left.{ }^{-1}\right)$ & $19^{-}$ & $8.19^{+}$ & $116.75^{\mathrm{ns}}$ \\
\hline 7. SL (150 mL ha $\left.{ }^{-1}\right)$ & $16^{-}$ & $7.95^{\mathrm{ns}}$ & $116.75^{\mathrm{ns}}$ \\
\hline 8. FS $\left(25 \mathrm{~mL} \mathrm{ha}^{-1}\right)$ & $54^{\mathrm{ns}}$ & $7.62^{\mathrm{ns}}$ & $114.00^{-}$ \\
\hline 9. FS $\left(50 \mathrm{~mL} \mathrm{ha}^{-1}\right)$ & $54^{\mathrm{ns}}$ & $7.58^{\text {ns }}$ & $114.00^{-}$ \\
\hline 10. FS $\left(75 \mathrm{~mL} \mathrm{ha}^{-1}\right)$ & $48^{\mathrm{ns}}$ & $7.62^{\mathrm{ns}}$ & $114.00^{-}$ \\
\hline Mean & 45 & 7.85 & 115.13 \\
\hline C.V.(\%) & 24.93 & 6.02 & 0.53 \\
\hline
\end{tabular}

${ }^{1} \mathrm{ST}=$ Seed Treatment; $\mathrm{SL}=$ Sowing Line; FS = Leaf spraying (between $\mathrm{V}_{5}$ and $\mathrm{V}_{6}$ stages); ${ }^{2}$ Means followed by (+) or (-) were either

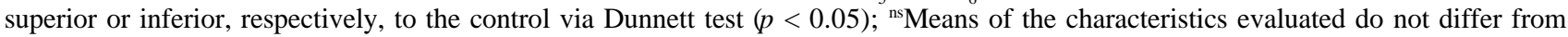
the control via Dunnett test $(p<0.05)$.

Table 2 - Mean number of pods per plant, number of seeds per plant, plant height, first pod insertion height, final stand, degree of plant layering, seed yield and one thousand seed weight in response to different doses and forms of bioregulator application on soybean culture as compared to the control (2004/2005).

\begin{tabular}{|c|c|c|c|c|c|c|c|c|}
\hline Treatment ${ }^{1} /$ Dose & $\begin{array}{c}\text { № of Pods } \\
\text { per Plant }\end{array}$ & $\begin{array}{c}\text { № of Seeds } \\
\text { per Plant }\end{array}$ & $\begin{array}{l}\text { Plant } \\
\text { Height }\end{array}$ & $\begin{array}{c}1^{\text {st }} \text { Pod } \\
\text { Insertion Height }\end{array}$ & $\begin{array}{l}\text { Final } \\
\text { Stand }\end{array}$ & $\begin{array}{c}\text { Layering } \\
\text { Degree }\end{array}$ & Yield & $\begin{array}{c}\text { One } \\
\text { Thousand } \\
\text { Seed Weight }\end{array}$ \\
\hline & & & $\ldots$ & cm - - & plants $\mathrm{m}^{-1}$ & & $\mathrm{~kg} \mathrm{ha}^{-1}$ & $\mathrm{~g}$ \\
\hline 1. CONTROL & $100.10^{2}$ & $212.00^{2}$ & $81.78^{2}$ & $17.03^{2}$ & $11.20^{2}$ & $1.25^{2}$ & $1649.25^{2}$ & $101.50^{2}$ \\
\hline 2. ST $\left(25 \mathrm{~mL} 100 \mathrm{~kg}^{-1}\right)$ & $77.40-$ & $156.30-$ & $86.58^{+}$ & $17.63^{\mathrm{ns}}$ & $14.40^{+}$ & $2.13^{+}$ & $2445.75^{+}$ & $113.73^{+}$ \\
\hline 3. ST $\left(50 \mathrm{~mL} 100 \mathrm{~kg}^{-1}\right)$ & $74.70-$ & $142.30-$ & $82.23^{\mathrm{ns}}$ & $17.43^{\text {ns }}$ & $13.90^{+}$ & $1.38^{\mathrm{ns}}$ & $2377.50^{+}$ & $110.54^{+}$ \\
\hline 4. ST $\left(75 \mathrm{~mL} 100 \mathrm{~kg}^{-1}\right)$ & 79.40- & $161.30-$ & $82.18^{\mathrm{ns}}$ & $16.85^{\mathrm{ns}}$ & $11.50^{\mathrm{ns}}$ & $1.50^{+}$ & $2304.25^{+}$ & $118.54^{+}$ \\
\hline 5. $\mathrm{SL}\left(50 \mathrm{~mL} \mathrm{ha}^{-1}\right)$ & $144.50^{+}$ & $366.80^{+}$ & $74.68^{-}$ & $12.78^{-}$ & $5.70^{-}$ & $1.00^{-}$ & $1968.50^{+}$ & $109.20^{+}$ \\
\hline 6. SL (100 mL ha-1) & $138.80^{+}$ & $374.50^{+}$ & $72.88^{-}$ & $12.80^{-}$ & $6.00^{-}$ & $1.00^{-}$ & $1941.75^{+}$ & $111.25^{+}$ \\
\hline 7. SL (150 mL ha-1) & $129.20^{+}$ & $310.50^{+}$ & $72.98^{-}$ & $12.40^{-}$ & $4.80^{-}$ & $1.00^{-}$ & $1408.25^{\mathrm{ns}}$ & $100.30^{-}$ \\
\hline 8. FS $\left(25 \mathrm{~mL} \mathrm{ha}^{-1}\right)$ & $80.20^{-}$ & $133.50^{-}$ & $82.98^{\mathrm{ns}}$ & $16.00^{\mathrm{ns}}$ & $11.30^{\mathrm{ns}}$ & $1.00^{-}$ & $2297.00^{+}$ & $99.98^{-}$ \\
\hline 9. FS (50 mL ha-1) & $82.90^{-}$ & $135.30^{-}$ & $86.83^{+}$ & $16.23^{\mathrm{ns}}$ & $13.20^{+}$ & $1.00^{-}$ & $2514.50^{+}$ & $112.77^{+}$ \\
\hline 10. FS $\left(75 \mathrm{~mL} \mathrm{ha}^{-1}\right)$ & $100.30^{\mathrm{ns}}$ & $205.80^{\mathrm{ns}}$ & $79.93^{-}$ & $13.30-$ & $10.90^{\mathrm{ns}}$ & $1.13^{\mathrm{ns}}$ & $3174.75^{+}$ & $122.01^{+}$ \\
\hline Means & 100.70 & 219.80 & 80.30 & 15.24 & 10.30 & 1.24 & 2208.15 & 109.98 \\
\hline C.V. $(\%)$ & 17.06 & 20.56 & 9.52 & 14.19 & 22.03 & 6.90 & 13.57 & 7.41 \\
\hline
\end{tabular}

${ }^{1} \mathrm{ST}=$ Seed Treatment; SL = Sowing Line; FS = Leaf spraying (between $\mathrm{V}_{5}$ and $\mathrm{V}_{6}$ stages); ${ }^{2}$ Means followed by $(+)$ or $(-)$ were either

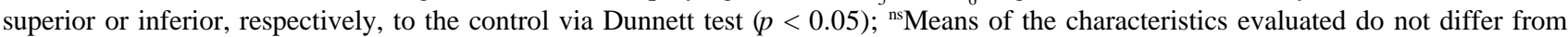
the control via Dunnett test $(p<0.05)$. 
were lower when compared to the control. Plant population is the factor that affects yields the least, provided that the plants are uniformly distributed in the area (Endres, 1996). Soybean crops compensate for density reduction by increasing the individual production of pods per plant (Peixoto, 1998).

The results on the average height of the plants and first pod insertion height have revealed that the treatments that had the shortest height of first pod insertion were those in which spraying was directed to the sowing line (Treatments 5 to 7). Treatments with taller plants than the control were those in which leaf spraying amounted to $50 \mathrm{~mL} \mathrm{ha}^{-1}$ or seed treatment to $25 \mathrm{~mL}$ $\mathrm{ha}^{-1}$ by bioregulator. There was no difference $(p<0.05)$ between other treatments and the control with regard to these characteristics. The small results for Treatments 5,6 and 7 are possibly due to their low stand caused by low emergence. Consequently, the lower the number of plants in each linear meter, the shorter the plant and first pod insertion heights when compared to established plant height with a recommended stand of 16 to 20 plants per meter (COODETEC, 2004).

Low seedling emergence led to a low final stand of plants, causing a morphological modification of soybean production components. In fact, the number of pods and seeds per plant was not negatively affected when compared to that of control; they were actually higher than those of control, compensating with a mass of one thousand seeds and yield in Treatments 5 and 6 . These results corroborate those obtained by Prete \& Watanabe (2006), who evaluated the effect of different cultivars, spaces and densities of sowing with regard to the agronomical characteristics of soybean culture. Plant reduction increased the number of branches, pods, seeds and consequently the mass of one thousand seeds.

Whereas the most plant layering was reported in Treatments 2 and 4, which correspond to product application in doses of 25 and $75 \mathrm{~mL} 100 \mathrm{~kg}^{-1}$, the least plant layering occurred in Treatments 5 to 9. The results corroborate those from plant heights; in other words, taller plants tend to lodge down. The final height of plants for Treatments 5; 6 and 7 was lower than that of the control; it was higher for Treatments 2;3 and 9. The bioregulator's promoting effect was evident in the case of plant height, exclusively for Treatments 2; 3 and 9. Doses by seed treatment and leaf spraying may have significantly affected the plants' physiological apparatus.

Seed yield was the variable with the greatest influence on doses and forms of product application, by which the best treatments were distinguished (Table 2). With the exception of Treatment 7, all treatments were higher than the control; Treatment 7 did not differ from the control. Highest average yield was ob- tained by Treatment $10\left(3,175 \mathrm{~kg} \mathrm{ha}^{-1}\right)$, corresponding to the highest dose of the product applied on leaves $\left(75 \mathrm{~mL} \mathrm{ha}^{-1}\right)$, with greater than $92 \%$ profit increase.

The control's low average yield may have occurred due to unfavorable climatic conditions at the end of the culture cycle, characterized by a long dry period, especially during February and March 2005 (Figure 1).

The bioregulator in soybean plants causes a more developed root system, with more vigorous roots and higher rates of dry matter, growth and total length when compared to non-treated plants (Castro \& Vieira, 1999). Such conditions produce a better and more extensive exploitation of soil resources, such as water and mineral nutrients. In fact, this is one of the aspects with a positive influence on plant yield; Vieira (2001) and Vieira \& Castro (2001) have found similar results.

Product application in different seed doses (Treatments 2 to 4 ) and the lowest doses of bioregulator ST10X in leaf spraying, (25 and 50 $\mathrm{mL} \mathrm{ha}{ }^{-1}$ ) Treatments 8 and 9, showed intermediate results, albeit higher than the control's. In contrast to the control (Treatment 1), yield profits by these treatments were $2.46 ; 48.29 ; 44.16 ; 39.72$ and $39.28 \%$, respectively, for Treatments 9, 2, 3, 4 and 8 . The only treatment with no difference $(p<0.05)$ when compared to the control was Treatment 7, the highest dose $\left(150 \mathrm{~mL} \mathrm{ha}^{-1}\right)$ of the product applied on the sowing line. Its average yield was $1,408 \mathrm{~kg} \mathrm{ha}^{-1}$ (Table 2). Application of bioregulator by seed treatment at concentration $5.0 \mathrm{~mL} 0.5 \mathrm{~kg}^{-1}$ of seeds has increased soybean plants' yield under controlled greenhouse conditions (Vieira \& Castro, 2001).

The evaluation of the mass of one thousand seed in all treatments was higher than that of the control, excepting Treatments 7 and 8. In these treatments, the mass of 1,000 seeds was lower than the control's (Table 2). The positive influence of treatments with regard to the control, even under the water stress circumstances reported during the period of culture development, may be due to the action of vegetal regulators in the bioregulator's composition. This fact may be attributed to the auxin on the plant rooting system. A deeply rooted plant exploits the soil more and, consequently, has a lesser propensity toward water stress during short dry periods. In fact, it has a higher capacity for absorbing the water and mineral salts available in the underlayers, thus warranting a faster allocation of substances to the plant's preferred discharges, such as the seeds.

Seeds produced by plants that received leaf spraying $\left(25 \mathrm{~mL} \mathrm{ha}^{-1}\right)$ and those with seeds treated with sowing line spraying $\left(150 \mathrm{~mL} \mathrm{ha}^{-1}\right)$ by bioregulator presented low vigor when compared to 
seeds produced by plants without any treatment (control), as shown in Table 3. Results refer to the germination test (first count) and to the classification test of seedling vigor. There was no difference $(p<0.05)$ in the tetrazolium test within the same treatments as compared to the control. Seeds produced by plants that received treatment before sowing time at $25 \mathrm{~mL} 100$ $\mathrm{kg}^{-1}$ seeds presented higher rates when compared to the control in all tests of physiological quality and seed protein amount. The exception lay with tests of seeds' health quality and oil quantity, since no difference $(p>0.05)$ was reported as compared to the control.

The best quality and highest quantity of oil and protein were obtained from seeds produced by plants with seeds treated before sowing with $75 \mathrm{~mL} 100 \mathrm{~kg}^{-1}$ of bioregulator ST10X, although with a lower yield with regard to $25 \mathrm{~mL} 100 \mathrm{~kg}^{-1}$ of bioregulator. Hormones may be involved in seed growth and development, including growth impairment (Bewley \& Black, 1994). They help give priority to seed maturation when accumulating and storing reserves in order to use them during germination and for fast seedling growth. Auxin may stimulate protein synthesis in soybean seeds. Nevertheless, this process may depend on the endogenous quantity of the phytohormone (Nascimento \& Mosquim, 2004). Results corroborate those found by Huizen et al. (1996) for pea seeds, who verified that exogenously applied gibberellin did not alter the seeds' protein content, even though $\mathrm{GA}_{3}$ levels were high during seed development. Cytokines applied in different concentrations generated an increase in the cotyledons' protein content. This fact indicates that phytohormones somewhat affect the production of proteins in soybean seeds (Nascimento \& Mosquim, 2004).

The application of phytoregulators, used alone and in combination with and at different concentrations, may affect the protein content in soybean seeds. Nevertheless, studies have reported that the increase in soybean seeds' protein content is in inverse proportion to oil content. Such a process may be affected by genotype and environment (Rangel et al., 2004). No difference $(p<0.05)$ exists for variables such as emergence speed of seedlings on field, cycle duration, degree of plant layering, final stand, plant height, first pod insertion height, number of pods per plant, number of seeds per plant, weight of 1,000 seeds and yield when the seed treatment was carried out (Table 4). Seedling emergence decreased in proportion to dose increase in seed treatment and all variables failed to show any differences $(p<0.05)$ with regard to dose used when seeds were treated by sowing line spraying (Table 4 ).

Throughout the experiment, the number of seeds per plant, the number of pods per plant, the mass of one thousand seeds, and the yield increased according to dose increase (Table 4). No difference $(p>0.05)$ was reported for variables such as germination (first and final count), classification of seedling vigor, tetrazolium (vigor and viability), health and oil and protein quantities in all forms of treatments. Responses were similar for all doses (Table 5).

Table 3 - Average results obtained from germination test (first ad final count), classification of seedling vigor, tetrazolium (vigor and viability), health test, and quantity of oil and protein tests in response to different doses and forms of bioregulator application on soybean culture as compared to the control (2004/2005).

\begin{tabular}{|c|c|c|c|c|c|c|c|c|}
\hline \multirow{2}{*}{ Treatment/Dose ${ }^{1}$} & \multicolumn{2}{|c|}{ Germination } & \multirow{2}{*}{$\begin{array}{c}\text { Classification of } \\
\text { Seedling Vigor }\end{array}$} & \multirow{2}{*}{ Vigor } & \multirow{2}{*}{ Viability } & \multirow{2}{*}{ Health } & \multirow{2}{*}{ Oil } & \multirow{2}{*}{ Proteins } \\
\hline & First Count & Final Count & & & & & & \\
\hline & & & & 0 & & & & \\
\hline 1. CONTROL & $81.25^{2}$ & $88.75^{2}$ & $84.12^{2}$ & $43.75^{2}$ & $92.50^{2}$ & $9.25^{2}$ & $17.77^{2}$ & $28.22^{2}$ \\
\hline 2. ST $\left(25 \mathrm{~mL} 100 \mathrm{~kg}^{-1}\right)$ & $86.75^{+}$ & $93.12^{+}$ & $88.62^{+}$ & $66.00^{+}$ & $90.50^{\mathrm{ns}}$ & $4.00^{\mathrm{ns}}$ & $18.25^{\mathrm{ns}}$ & $29.22^{+}$ \\
\hline 3. $\mathrm{ST}\left(50 \mathrm{~mL} 100 \mathrm{~kg}^{-1}\right)$ & $81.62^{\mathrm{ns}}$ & $88.50^{\mathrm{ns}}$ & $85.87^{\mathrm{ns}}$ & $69.50^{+}$ & $91.50^{\mathrm{ns}}$ & $8.25^{\mathrm{ns}}$ & $17.47^{\mathrm{ns}}$ & $28.05^{\mathrm{ns}}$ \\
\hline 4. ST $\left(75 \mathrm{~mL} 100 \mathrm{~kg}^{-1}\right)$ & $87.62^{+}$ & $92.37^{+}$ & $89.50^{+}$ & $68.87^{+}$ & $91.75^{\mathrm{ns}}$ & $6.75^{\mathrm{ns}}$ & $20.27^{+}$ & $31.92^{+}$ \\
\hline 5. $\mathrm{SL}\left(50 \mathrm{~mL} \mathrm{ha}{ }^{-1}\right)$ & $83.12^{\mathrm{ns}}$ & $90.00^{\mathrm{ns}}$ & $86.75^{\mathrm{ns}}$ & $63.75^{+}$ & $92.00^{\mathrm{ns}}$ & $10.25^{\mathrm{ns}}$ & $17.09^{\mathrm{ns}}$ & $27.48^{-}$ \\
\hline 6. SL (100 mL ha-1) & $83.87^{\mathrm{ns}}$ & $89.00^{\mathrm{ns}}$ & $87.50^{\mathrm{ns}}$ & $68.50^{+}$ & $89.75^{-}$ & $26.00^{+}$ & $16.51^{-}$ & $27.99^{-}$ \\
\hline 7. SL (150 $\left.\mathrm{mL} \mathrm{ha}^{-1}\right)$ & $70.25^{-}$ & $81.87^{\mathrm{ns}}$ & $78.37^{-}$ & $42.25^{\mathrm{ns}}$ & $91.25^{\mathrm{ns}}$ & $24.25^{+}$ & $18.05^{\text {ns }}$ & $29.64^{+}$ \\
\hline 8. FS (25 mL ha-1) & $74.50^{-}$ & $86.25^{\mathrm{ns}}$ & $77.62^{-}$ & $55.75^{\mathrm{ns}}$ & $84.50^{-}$ & $30.25^{+}$ & $17.11^{\mathrm{ns}}$ & $27.48^{-}$ \\
\hline 9. FS $\left(50 \mathrm{~mL} \mathrm{ha}^{-1}\right)$ & $80.62^{\mathrm{ns}}$ & $91.00^{\mathrm{ns}}$ & $86.37^{\mathrm{ns}}$ & $68.00^{+}$ & $90.75^{\mathrm{ns}}$ & $27.50^{+}$ & $18.04^{\mathrm{ns}}$ & $29.85^{+}$ \\
\hline 10. FS $\left(75 \mathrm{~mL} \mathrm{ha}^{-1}\right)$ & $79.00^{\mathrm{ns}}$ & $88.75^{\mathrm{ns}}$ & $85.25^{\mathrm{ns}}$ & $65.75^{+}$ & $91.75^{\mathrm{ns}}$ & $21.50^{+}$ & $18.28^{\mathrm{ns}}$ & $30.88^{+}$ \\
\hline Mean & 80.86 & 88.96 & 84.99 & 61.21 & 90.62 & 19.22 & 17.88 & 29.07 \\
\hline C.V.(\%) & 10.13 & 6.00 & 9.58 & 16.38 & 5.28 & 45.95 & 5.14 & 7.28 \\
\hline
\end{tabular}

${ }^{1} \mathrm{ST}=$ Seed Treatment; SL = Sowing Line; FS = Leaf spraying (between V5 and $\mathrm{V}_{6}$ stages); ${ }^{2}$ Mean followed by (+) or (-) were either

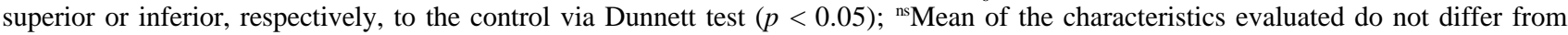
the control via Dunnett test $(p<0.05)$. 
Table 4 - Response to different forms of application in relation to different doses of bioregulator on soybean culture with regard to the behavior of the averages of total percentage of seedling emergence on field, emergence speed, cycle duration, degree of plant layering, final stand, plant height, first pod insertion height, number of pods per plant, number of seeds per plant, one thousand seed weight and seed yield, Maringá, PR (2004/2005).

\begin{tabular}{|c|c|c|c|c|c|c|}
\hline \multirow[b]{2}{*}{$\begin{array}{l}\text { Characteristics } \\
\text { Evaluated }\end{array}$} & \multicolumn{6}{|c|}{ Form of Treatment } \\
\hline & Seed Treatment & $\begin{array}{l}\text { Coefficient of } \\
\text { Determination } \\
\qquad\left(\mathrm{R}^{2}\right)\end{array}$ & $\begin{array}{l}\text { Pulverization } \\
\text { in the } \\
\text { Sowing Line }\end{array}$ & $\begin{array}{l}\text { Coefficient of } \\
\text { Determination } \\
\left(\mathrm{R}^{2}\right)\end{array}$ & Leaf Spraying & $\begin{array}{c}\text { Coefficient of } \\
\text { Determination } \\
\left(\mathrm{R}^{2}\right)\end{array}$ \\
\hline Emergence & $\hat{\mathrm{Y}}=-0.28 \mathrm{X}+76.66$ & 0.85 & $\hat{\mathrm{Y}}=\overline{\mathrm{Y}}=17.33$ & - & $\hat{\mathrm{Y}}=\overline{\mathrm{Y}}=53.33$ & - \\
\hline $\begin{array}{l}\text { Emergence } \\
\text { Speed }\end{array}$ & $\hat{\mathrm{Y}}=\overline{\mathrm{Y}}=62.66$ & - & $\hat{\mathrm{Y}}=\overline{\mathrm{Y}}=17.33$ & - & $\hat{\mathrm{Y}}=\mathrm{Y}^{-}=53.33$ & - \\
\hline Cycle & $\hat{\mathrm{Y}}=\overline{\mathrm{Y}}=114.33$ & - & $\hat{\mathrm{Y}}=\overline{\mathrm{Y}}=116.66$ & - & $\hat{\mathrm{Y}}=\overline{\mathrm{Y}}=114.00$ & - \\
\hline Layering & $\hat{\mathrm{Y}}=\overline{\mathrm{Y}}=1.67$ & - & $\hat{\mathrm{Y}}=\overline{\mathrm{Y}}_{-}=1.00$ & - & $\hat{\mathrm{Y}}=\overline{\mathrm{Y}}=1.56$ & - \\
\hline Final Stand & $\hat{\mathrm{Y}}=\overline{\mathrm{Y}}=13.26$ & - & $\hat{\mathrm{Y}}=\overline{\mathrm{Y}}=5.5$ & - & $\hat{\mathrm{Y}}=\overline{\mathrm{Y}}_{-}=11.80$ & - \\
\hline Plant Height & $\hat{\mathrm{Y}}=\overline{\mathrm{Y}}=83.66$ & - & $\hat{\mathrm{Y}}=\overline{\mathrm{Y}}=73.51$ & - & $\hat{\mathrm{Y}}=\mathrm{Y}=83.28$ & - \\
\hline $\begin{array}{l}\text { First Pod } \\
\text { Insertion }\end{array}$ & $\hat{\mathrm{Y}}=\overline{\mathrm{Y}}=17.19$ & - & $\hat{Y}=\bar{Y}=12.66$ & - & $\hat{\mathrm{Y}}=\overline{\mathrm{Y}}=15.17$ & - \\
\hline Pods per Plant & $\hat{\mathrm{Y}}=\underline{\bar{Y}}=77.16$ & - & $\hat{\mathrm{Y}}=\overline{\mathrm{Y}}=137.50$ & - & $\hat{\mathrm{Y}}=0.40 \mathrm{X}+67.70$ & 0.84 \\
\hline Seeds per Plant & $\hat{\mathrm{Y}}=\overline{\mathrm{Y}}=153.30$ & - & $\hat{\mathrm{Y}}=\overline{\mathrm{Y}}=350.60$ & - & $\hat{\mathrm{Y}}=\overline{\mathrm{Y}}=158.20$ & - \\
\hline $\begin{array}{l}\text { One Thousand } \\
\text { Seed Weight }\end{array}$ & $\hat{\mathrm{Y}}=\overline{\mathrm{Y}}=114.27$ & - & $\hat{\mathrm{Y}}=\underline{-} \overline{\mathrm{Y}}=103.84$ & - & $\hat{\mathrm{Y}}=0.44 \mathrm{X}+89.55$ & 0.99 \\
\hline Yield & $\hat{\mathrm{Y}}=\overline{\mathrm{Y}}=2662$ & - & $\hat{\mathrm{Y}}=\mathrm{Y}=1773$ & - & $\hat{Y}=17.55 X+1784$ & 0.92 \\
\hline
\end{tabular}

Table 5 - Response to different forms of application in relation to different doses of bioregulator on soybean culture with regard to the behavior of the averages of germination test (first and final count), classification of seedling vigor, tetrazolium (vigor and viability), health test and quantities of oil and protein, Maringá, PR (2004/2005).

\begin{tabular}{|c|c|c|c|}
\hline \multirow[b]{2}{*}{ Characteristics Evaluated } & \multicolumn{3}{|c|}{ Form of Treatment } \\
\hline & Seed Treatment & $\begin{array}{l}\text { Pulverization into the } \\
\text { Sowing Line }\end{array}$ & Leaf spraying \\
\hline First Count & $\hat{\mathrm{Y}}=\overline{\mathrm{Y}}=85.33$ & $\hat{\mathrm{Y}}=\overline{\mathrm{Y}}=79.08$ & $\hat{\mathrm{Y}}=\overline{\mathrm{Y}}=78.04$ \\
\hline Germination & $\hat{\mathrm{Y}}=\overline{\mathrm{Y}}=91.30$ & $\hat{\mathrm{Y}}=\overline{\mathrm{Y}}=86.95$ & $\hat{\mathrm{Y}}=\overline{\mathrm{Y}}=88.66$ \\
\hline $\begin{array}{l}\text { Classification of Seedling } \\
\text { Vigor }\end{array}$ & $\hat{Y}=\bar{Y}=87.99$ & $\hat{\mathrm{Y}}=\overline{\mathrm{Y}}=84.20$ & $\hat{Y}=\bar{Y}=83.08$ \\
\hline Vigor & $\hat{\mathrm{Y}}=\overline{\mathrm{Y}}=68.12$ & $\hat{\mathrm{Y}}=\overline{\mathrm{Y}}=84.20$ & $\hat{\mathrm{Y}}=\overline{\mathrm{Y}}=63.16$ \\
\hline Viability & $\hat{\mathrm{Y}}=\overline{\mathrm{Y}}=91.25$ & $\hat{\mathrm{Y}}=\overline{\mathrm{Y}}=91.00$ & $\hat{Y}=\bar{Y}=89.00$ \\
\hline Health & $\hat{Y}=\bar{Y}=6.33$ & $\hat{\mathrm{Y}}=\overline{\mathrm{Y}}=20.16$ & $\hat{Y}=\bar{Y}=26.41$ \\
\hline Oil & $\hat{\mathrm{Y}}=\overline{\mathrm{Y}}=17.21$ & $\hat{\mathrm{Y}}=\overline{\mathrm{Y}}=17.81$ & $\hat{Y}=\bar{Y}=29.73$ \\
\hline Proteins & $\hat{\mathrm{Y}}=\overline{\mathrm{Y}}=29.73$ & $\hat{\mathrm{Y}}=\overline{\mathrm{Y}}=28.37$ & $\hat{\mathrm{Y}}=\overline{\mathrm{Y}}=15.17$ \\
\hline
\end{tabular}

\section{REFERENCES}

ALLEONI, B.; BOSQUEIRO, M.; ROSSI, M. Estudo dos reguladores vegetais de Stimulate no desenvolvimento e produtividade do feijoeiro (Phaseolus vulgaris). Publicatio UEPG, v.6, p.23-35, 2000.

ASSOCIATION OF OFFICIAL ANALYTICAL CHEMISTS AOAC. Official methods of analysis. Washington, D.C.: AOAC, 1975. 1054p.

BEWLEY, J.D.; BLACK, M. Seeds: physiology of development and germination. 2. ed. New York: Plenum Press, 1994. 445p.

BRACCINI, A.L.; MONFERDINI, M.A.; ÁVILA, M.R.; SCAPIM, C.A.; BRAMBILLA, D.; ARAGÃO, R.M.; BRAMBILLA, T. Emergência das plântulas e componentes da produção de sementes em resposta a diferentes doses e formas de aplicação do bioestimulante Stimulate 10X na cultura da soja. In: REUNIÃO DE PESQUISA DE SOJA DA REGIÃO CENTRAL DO BRASIL, 27., Cornélio Procópio, 2005. Resumos Expandidos. Londrina: Embrapa Soja, 2005. p.565-566.
BRASIL. Ministério da Agricultura e Reforma Agrária. Regras para análise de sementes. Brasília: SNDA/DNDV/CLAV, 1992. 365p.

CASILLAS, V.J.C.; LONDOÑO, I.J.; GUERRERO, A.H.; BUITRAGO, G.L.A. Analisis cuantitativo de la aplicacion de cuatro bioestimulantes en el cultivo del rabano (Raphanus sativus L.). Acta Agronomica, v.36, p.185-195, 1986.

CASTRO, P.R.C. Efeitos de reguladores de crescimento em soja (Glycine max (L.) Merrill cv. Davis). Piracicaba: ESALQ/ USP, 1980. 174p. (Tese Livre Docência).

CASTRO, P.R.C.; MELOTTO, E. Bioestimulantes e hormônios aplicados via foliar. In: BOARETO, A.E.; ROSOLEM, C.A. (Ed.) Adubação foliar. Campinas: Fundação Cargill, 1989. v.1, cap.8, p. 191-235.

CASTRO, P.R.C.; VIEIRA, E.L. Utilização de rizotrons para a avaliação do desenvolvimento do sistema radicular de sementes de soja (Glycine max L.) sob pré-tratamentos com Stimulate. In: CONGRESSO BRASILEIRO DE FISIOLOGIA VEGETAL, 7., Brasília, 1999. Resumos. Brasília: SBFV, 1999. p.60. 
CASTRO, P.R.C.; VIEIRA, E.L. Aplicações de reguladores vegetais na agricultura tropical. Guaíba: Agropecuária, 2001. 132p.

COOPERATIVA CENTRAL DE PESQUISA AGRÍCOLA COODETEC. Prospecto técnico de cultivares de soja. Cascavel: COODETEC, 2004. 68p.

EDMOND, J.B.; DRAPALA, W.J. The effects of temperature, sand and soil, and acetone on germination of okra seeds. American Society for Horticultural Science, v.71, p.428-434, 1958.

EMBRAPA SOJA. Tecnologias de produção de soja: Paraná 2005. Londrina: Embrapa Soja, 2004. 224p. (Sistemas de Produção, 5).

ENDRES, V.C. Espaçamento, densidade e época de semeadura. In: EMBRAPA. Centro de Pesquisa Agropecuária do Oeste. Soja: recomendações técnicas para Mato Grosso do Sul e Mato Grosso. Dourados: Embrapa CPAO, 1996. p.82-85. (Circular Técnica, $3)$.

FEHR, W.R.; CAVINESS, C.E.; GURMOOD, D.T.; PENNINGTON, J.S. Stage of development description for soybean, Glycine max (L.) Merrill. Crop Science, v.11, p.929-931, 1971.

FRANÇA NETO, J.B.; KRZYZANOWSKI, F.C.; COSTA, N.P.; HENNING, A.A. O teste de tetrazólio em sementes de soja. Londrina: EMBRAPA-CNPSo, 1998. 72p. (EMBRAPACNPSo. Documentos, 116).

FRANÇA NETO, J.B.; KRZYZANOWSKI, F.C.; COSTA, N.P. Metodologia do teste de tetrazólio em sementes de soja. In: KRZYZANOWSKI, F.C.; VIEIRA, R.D.; FRANÇA NETO, J.B. (Ed.) Vigor de sementes: conceitos e testes. Londrina: ABRATES, 1999. cap.8.5, p.1-28.

HENNING, A.A. Patologia de sementes. Londrina: EMBRAPACNPSo, 1994. 43p. (Documentos, 90).

HUIZEN, R. van; OZGA, J.A.; REINECKE, D.M. Influence of auxin and gibberellin on in vivo protein synthesis during early pea fruit growth. Plant Physiology, v.112, p.53-59, 1996.

INSTITUTO ADOLFO LUTZ - IAL. Normas analíticas do Instituto Adolfo Lutz: métodos químicos e físicos para análise de alimentos. São Paulo: IAL, 1985. v.1, 533p.

INSTITUTO AGRONÔMICO DO PARANÁ - IAPAR. Cartas climáticas básicas do Estado do Paraná. Londrina: IAPAR, 1987. 35p.

LARCHER, W.; PRADO, C.H.D.A. Ecofisiologia vegetal. São Carlos: Rima, 2000. p.341-418.

MARCOS FILHO, J. Fisiologia de sementes de plantas cultivadas. Piracicaba: Fealq, 2005. p.197-252.

MORAIS, C.R.A.; MODOLO, V.A.; CASTRO, P.R.C. Fisiologia da germinação. In.: CASTRO, P.R.C.; SENA, J.O.A.; KLUGE, R.A (Ed.) Introdução à fisiologia do desenvolvimento vegetal. Maringá: EDUEM, 2002. cap.10, p.159-178.
NASCIMENTO, R.; MOSQUIM, P.R. Crescimento e teor de proteínas em sementes de soja sob influência de hormônios vegetais. Revista Brasileira de Botânica, v.27, p.573-579, 2004.

NAKAGAWA, J. Testes de vigor baseados no desempenho das plântulas. In: KRZYZANOWSKI, F.C.; VIEIRA, R.D.; FRANÇA NETO, J.B. (Ed.) Vigor de sementes: conceitos e testes. Londrina: ABRATES, 1999. cap.2, p.1-24.

NICKELL, L.G. Plant growth regulating chemicals. Boca Raton: CRC Press, 1988. 2v.

PEIXOTO, C.P. Análise de crescimento e rendimento de três cultivares de soja em três épocas de semeadura e três densidades de plantio. Piracicaba: USP/ESALQ, 1998. 151p. (Doutorado).

POPINIGIS, F. Fisiologia da semente. Brasília: AGIPLAN, 1985. $289 \mathrm{p}$.

PRETE, C.E.C.; WATANABE, T.S. Efeito de cultivar, espaçamento e densidade de plantio sobre características agronômicas da soja. In: CONGRESSO BRASILEIRO DE SOJA, 4., Londrina, 2006. Resumos. Londrina: Embrapa Soja, 2006. p.29.

RANGEL, M.A.S.; CAVALHEIRO, L.R.; CAVICHIOLLI, D.; CARDOSO, P.C. Efeito do genótipo e do ambiente sobre os teores de óleo e proteína nos grãos de soja, em quatro ambientes da região sul de Mato Grosso do Sul, safra 2002/2003. Dourados: Embrapa Agropecuária Oeste, 2004. 20p. (Boletim de Pesquisa e Desenvolvimento, 17).

TAIZ, L.; ZEIGER, E. Fisiologia vegetal. 3. ed. Porto Alegre: Artmed, 2004. 613p.

VIEIRA, E.L. Ação de bioestimulante na germinação de sementes, vigor de plântulas, crescimento radicular e produtividade de soja (Glycine max (L.) Merrill), feijoeiro (Phaseolus vulgaris L.) e arroz (Oryza sativa L.). Piracicaba: USP/ESALQ, 2001. 122p. (Doutorado).

VIEIRA, E.L.; CASTRO, P.R.C. Ação de bioestimulante na germinação de sementes, vigor de plântulas, crescimento radicular e produtividade de soja. Revista Brasileira de Sementes, v.23, p.222-228, 2001

VIEIRA, E.L.; CASTRO, P.R.C. Ação de bioestimulante na cultura da soja (Glycine max (L.) Merrill). Cosmópolis: Stoller do Brasil Ltda., 2004. 74p.

Received February 12, 2007

Accepted February 27, 2008 